\title{
PENGARUH BERBAGAI JENIS DAN DOSIS PUPUK ORGANIK TERHADAP PERTUMBUHAN DAN PRODUKSI TANAMAN HOTONG (Setaria italica [L.] Beauv)
}

\author{
Masita $^{(1)}$, J. F. Rehena ${ }^{(2)}$, John Riry ${ }^{(2)}$, Ali Awan ${ }^{(2)}$ \\ (1) Alumni Mahasiswa Magister Pendidikan Biologi \\ (2) Dosen Magister Pendidikan Biologi \\ e-mai: masita_pascabio@yahoo.com
}

\begin{abstract}
Background: One type of organic fertilizer is manure that contains nutrients that can support the growth of microorganisms in soil fertility and soil. On the island of Buru, the people there know and cultivate community hotong normally used as a traditional food.

Methods: This study was conducted in the District Three Village house Baguala, which lasted for four months ie from March to June 2015. The study was conducted in the form of two factor experiment in a randomized complete block design (RAK). The first factor (I) is a type of organic fertilizer (F), which consists of 4 levels of treatment and the second factor (II) is a dose of organic fertilizer (M) comprising 5 stage treatment. Observations were made on indicators of growth in terms of height and number of leaves and production indicators include the number of tillers $(\mathrm{JA})$, the number of panicle (JM), panicle length (PM), planting seed weight (BBP), and the dry weight of stover (BKB).

Results: The existence of the effect of the type of organic fertilizer on the growth and poduksi plant hotong seen in the treatment of type of fertilizer week 8 is on F3 and F4 showed high growth of crops, leaf number ever, the number of panicle most, the number of tillers most, panicle length of the longest and most planting seed weight and dry weight of stover. The influence dose of organic fertilizer on the growth and yield of hotong look at treatment week 8, namely the treatment of M2, M3 and M4 showed high growth of crops and the number of leaves, the highest and the treatment number of panicles and tillers most, panicle length of the longest as well as the weight of seed planting and a dry weight of stover. Recommendations effective fertilizer in crop cultivation hotong is to use the type of chicken manure and cow with doses of 900 and $1200 \mathrm{~g} /$ polybag.

Conclusion: The interaction between treatment types of fertilizers and fertilizers at the variable growth in terms of height (TT) and number of leaves (JD) as well as for variable production panicle length (PM), the weight of the seed crop (BBP) and the dry weight of stover (BKB) showed their influence the type and dose of fertilizer on each variable hotong growth and crop production, reflected in the growth and crop production hotong diverse in every treatment.
\end{abstract}

Keywords: Dose, Type, Organic Fertilizer, Growth, Production, Plant Hotong.

\begin{abstract}
Abstrak
Latar Belakang: Salah satu jenis pupuk organik adalah pupuk kandang yang memiliki kandungan hara yang dapat mendukung kesuburan tanah dan pertumbuhan mikroorganisme tanah. Di pulau Buru, masyarakat di sana telah mengenal dan membudidayakan hotong yang biasanya digunakan masyarakat sebagai makanan tradisional.

Metode: Penelitian ini dilaksanakan di Desa Rumah Tiga Kecamatan Baguala, yang berlangsung selama 4 bulan yakni dari bulan Maret hingga Juni 2015. Penelitian ini dilaksanakan dalam bentuk percobaan 2 faktor dalam rancangan acak kelompok (RAK). Faktor pertama (I) adalah jenis pupuk organik (F) yang terdiri dari 4 taraf perlakuan dan Faktor kedua (II) adalah dosis pupuk organik (M) yang terdiri dari 5 taraf perlakuan. Pengamatan dilakukan pada indikator pertumbuhan meliputi tinggi tanaman dan jumlah daun serta indikator produksi meliputi jumlah anakan (JA), jumlah malai (JM), panjang malai (PM), bobot biji pertanaman (BBP), dan bobot kering brangkasan (BKB).

Hasil: Adanya pengaruh pemberian jenis pupuk organik terhadap pertumbuhan dan poduksi tanaman hotong terlihat pada perlakuan jenis pupuk minggu ke-8 yaitu pada F3 dan F4 menunjukan pertumbuhan tinggi tanaman tertinggi, jumlah daun terbanyak, jumlah malai terbanyak, jumlah anakan terbanyak, panjang malai terpanjang dan bobot biji pertanaman terbanyak serta bobot kering brangkasan. Adanya pengaruh dosis pupuk organik terhadap pertumbuhan dan produksi tanaman hotong terlihat pada
\end{abstract}


perlakuan minggu ke-8 yaitu pada perlakuan M2, M3 dan M4 menunjukan pertumbuhan tinggi tanaman tertinggi dan jumlah daun terbanyak serta perlakuan jumlah malai dan anakan terbanyak, panjang malai terpanjang serta bobot biji pertanaman dan bobot kering brangkasan. Rekomendasi pupuk yang efektif dalam pembudidayaan tanaman hotong adalah dengan penggunaan jenis pupuk kandang ayam dan sapi dengan dosis pemberian 900 dan $1200 \mathrm{~g} /$ polybag.

Kesimpulan: Interaksi antara perlakuan jenis pupuk dan dosis pupuk pada peubah pertumbuhan meliputi tinggi tanaman (TT) dan jumlah daun (JD) serta untuk peubah produksi panjang malai (PM), bobot biji pertanaman (BBP) dan bobot kering brangkasan (BKB) menunjukan adanya pengaruh jenis dan dosis pupuk pada tiap peubah pertumbuhan dan produksi tanaman hotong, terlihat dari pertumbuhan dan produksi tanaman hotong yang beragam pada tiap perlakuan.

Kata kunci: Dosis, Jenis, Pupuk Organik, Pertumbuhan, Produksi, Tanaman Hotong.

\section{PENDAHULUAN}

Tanaman palawija seperti jagung, padi, gandum dan hotong merupakan beberapa komuditas pangan yang ditanam pada lahan kering. Salah satu komuditas pangan yang cukup penting adalah tanaman hotong (Setaria italica (L.) Beauv) merupakan salah satu tanaman sejenis alang-alang yang berasal dari pulau Buru Maluku. Tanaman hotong mempunyai kandungan gizi yang hampir mirip dengan tanaman padi. Menurut Balitseral (2004) dalam Hildayanti (2012) mengemukakan bahwa kandungan gizi tanaman hotong tiap $100 \mathrm{~g}$ biji mengandung karbohidrat 84.2, protein 10.7, lemak 3.3, serat kasar 1.4 dan kadar abu 3.0.

Menurut Tim Pengembangan Hotong Buru (2006) dari analisis laboratorium memperlihatkan bahwa kandungan karbohidrat biji hotong sama seperti pada beras, sedangkan kandungan protein dan lemaknya lebih tinggi bila dibandingkan dengan beras. Dengan kandungan gizi yang tinggi serta didukung dengan harga yang relatif murah, maka tanaman hotong dapat dikonsumsi sebagai bahan pangan yang dapat mencukupi kebutuhan gizi masyarakat.

Di Maluku khususnya di pulau Buru, masyarakat di sana telah mengenal dan membudidayakan hotong yang biasanya digunakan masyarakat sebagai makanan tradisional. Hotong di gunakan sebagai makanan pokok oleh masyarakat di lokasi ini disamping umbi-umbian dan sagu (Rumbawer, 2003). Salah satu faktor yang mempengaruhi produktivitas lahan pertanian adalah penggunaan pupuk. Upaya yang di harapkan berperan dalam peningkatan produktivitas tanaman hotong yaitu dapat dilakukan dengan kegiatan pemupukan. Menurut Lingga dan Marsono., (2000) pemupukan bertujuan untuk dapat menambah kandungan unsur hara di dalam tanah, sehingga dapat diperbaiki struktur tanah. Dalam proses pemupukan, pupuk yang digunakan adalah pupuk yang ramah lingkungan. Hal ini dapat dilakukan dengan pemanfaatan pupuk alami seperti pupuk organik. pupuk organik adalah sumber nutrisi yang efektif untuk meningkatkan kualitas tanah dalam jangka waktu yang panjang (Boonsiri, et al., 2009).

Salah satu jenis pupuk organik adalah pupuk kandang yang memiliki kandungan hara yang dapat mendukung kesuburan tanah dan pertumbuhan mikroorganisme tanah. Pemberian pupuk kandang selain dapat mendukung pertumbuhan mikroorganisme juga mampu memperbaiki struktur tanah (Mayadewi, 2007). Dalam pemberian pupuk perlu diperhatikan kebutuhan dari tanaman tersebut, agar tanaman tidak terlalu banyak zat makanan. Terlalu sedikit atau terlalu banyak zat makanan dapat berbahaya bagi tanaman. Ada beberapa jenis pupuk organik yang dapat digunakan diantaranya yaitu pupuk kandang ayam, kambing, sapi dan salah satu jenis pupuk organik lainnya yaitu bokashi.

\section{METODE}

Penelitian ini dilaksanakan di Desa Rumah Tiga Kecamatan Baguala, yang berlangsung selama 4 bulan yakni dari bulan Maret hingga Juni 2015. Bahan-bahan yang digunakan dalam penelitian ini meliputi benih hotong (Setaria italica), furadan $3 \mathrm{G}$, daun gamal, kotoran ayam, kotoran kambing, kotoran sapi, EM4, gula pasir, dedak dan air. Alat-alat yang digunakan dalam penelitian ini meliputi polybag dengan 
ukuran $40 \times 40 \mathrm{~cm}$, cangkul, terpal, parang, timbangan duduk, karung, farlak plastik, hekter, kayu, ember, tali arafia, plastik gula, label, meter, timbangan analitik, penggaris, kamera dan alat tulis menulis.

\section{a. Rancangan Percobaan}

Penelitian ini dilaksanakan dalam bentuk percobaan 2 faktor dalam rancangan acak kelompok (RAK). Faktor pertama (I) adalah jenis pupuk organik $(F)$ yang terdiri dari 4 taraf perlakuan yaitu:

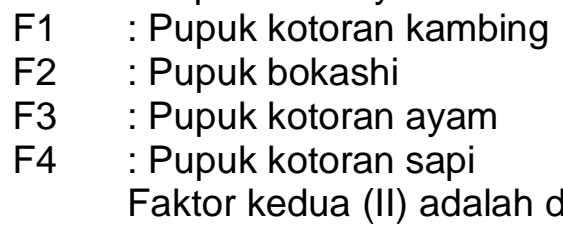

organik (M) perlakuan:

$$
\begin{aligned}
& \text { M0 : Kontrol } \\
& \text { M1 : } 10 \text { ton/ha }=300 \mathrm{~g} / \text { polybag } \\
& \text { M2 : } 20 \text { ton/ha } \quad=600 \mathrm{~g} / \text { polybag } \\
& \text { M3 : } 30 \text { ton/ha }=900 \mathrm{~g} / \text { polybag } \\
& \text { M4 : } 40 \text { ton/ha }=1200 \mathrm{~g} / \text { polybag } \\
& \text { Setiap perlakuan dikombinasikan, } \\
& \text { sehingga terdapat } 20 \text { kombinasi perlakuan. } \\
& \text { Setiap perlakuan diulang sebanyak } 3 \text { kali, } \\
& \text { sehingga seluruhnya terdapat } 60 \text { satuan } \\
& \text { percobaan yang akan digunakan. }
\end{aligned}
$$

\section{b. Persiapan Media Tanam}

Media tanam berupa tanah yang telah diayak dan dibersihkan dari batu-batu kecil dan kotoran seperti akar-akar kayu. Siapkan polybag dengan ukuran $40 \times 40 \mathrm{~cm}$, kemudian polybag diisi dengan tanahnya seberat $10 \mathrm{~kg}$. Pada setiap polybag diberikan label sesuai dengan perlakuan dilapangan, kemudian diletakan secara acak. Pada polybag dengan perlakuan pupuk diberikan pupuk sesuai dengan perlakuan. Dimana perlakuan pupuk F1 (pupuk kotoran kambing) 10 ton/ha yang telah dikonversikan ke g/lubang tanam yaitu $300 \mathrm{~g} /$ polybag, pada perlakuan F2 (pupuk bokashi) 20 ton/ha yang telah dikonversikan ke g/lubang tanam sebanyak $600 \mathrm{~g} /$ polybag, pada perlakuan F3 (pupuk kotoran ayam) 30 ton/ha yang telah dikonversikan ke g/lubang tanam sebesar 900 g/polybag, dan perlakuan F4 (pupuk kotoran sapi) 40 ton/ha yang telah di konversikan ke g/lubang tanam sebesar $1200 \mathrm{~g} /$ polybag. Pada tiap polybag diberikan air selama 1 minggu sebelum penanaman.

\section{c. Persiapan Bahan Tanam}

Benih yang digunakan dalam penelitian ini adalah benih tanaman hotong yang berasal dari Kabupaten Buru. Benih yang baru dipanen dan dibeli langsung dari masyarakat di Desa Waeperang.

\section{d. Pembuatan Bokashi}

Bokashi yang digunakan dalam penelitian ini adalah bokashi yang dibuat sendiri. Bahan-bahan yang digunakan adalah daun gamal, dedak, pupuk kandang ayam, EM4, gula pasir dan air.

\section{e. Penanaman}

Membuat lubang tanam, lubang tanam dibuat sedalam $0,5 \mathrm{~cm}$. Jumlah benih setiap lubang tanam berisi 3-5 benih. Kemudian diberi furadan $3 \mathrm{G}$ diberikan pada lubang tanam yang telah berisi benih dengan dosis $2 \mathrm{~g} / \mathrm{lubang}$ tanam. Mengatur jarak tanam antara polybag adalah $50 \times 60 \mathrm{~cm}$.

\section{f. Pemupukan}

Pupuk organik yang digunakan adalah F1 (pupuk kotoran kambing) 10 ton/ha yang telah di konversikan ke gram/lubang tanam sebesar $300 \mathrm{~g} /$ polybag $(0,100,300,350$, dan 400 g/polybag), F2 (pupuk bokashi) 20 ton/ha yang telah dikonversikan ke gram/lubang tanam sebesar $600 \mathrm{~g} /$ polybag (0, 300, 400, 600, $800 \mathrm{~g} /$ polybag), F3 (pupuk kotoran ayam) 30 ton/ha yang telah di konversikan ke gram/lubang tanam sebesar $900 \mathrm{~g} /$ polybag (0, 700, 850, 900, 1000 g/polybag) dan F4 (pupuk kotoran sapi) 40 ton/ha yang telah dikonversikan ke gram/lubang tanam sebesar $1200 \mathrm{~g} /$ polybag $(0,1000,1200,1300,1350 \mathrm{~g} /$ polybag $)$.

Pemberian pupuk organik dilakukan 1 minggu sebelum tanam dengan cara dicampurkan dalam lubang tanam yang tanam.

\section{g. Pemeliharaan Tanaman Hotong 1) Penyiraman}

Penyiraman merupakan salah satu syarat yang harus dilakukan dalam budidaya tanaman. Penyiraman dilakukan dengan cara menggunakan gembor dilakukan dua kali yaitu pada pagi dan sore hari atau disesuaikan dengan keadaan cuaca pada saat itu, tetapi apabila tanah masih dalam 
keadaan lembab maka tidak dilakukan penyiraman.

\section{2) Penjarangan}

Penjarangan dilakukan 5-7 hari setelah tanam (HST) yaitu hanya menyisahkan 2 tanaman per polybag.

\section{3) Penyiangan}

Gulma merupakan himpunan jenis tumbuhan yang hidupnya atau tumbuhnya tidak dikehendaki karena dianggap mengganggu dan dapat menurunkan hasil tanaman yang dibudidayakan. Penyiangan dilakukan dari awal tanam sampai menjelang panen terhadap rumput-rumput liar yang tumbuh disekitar tanaman hotong yang menjadi pesaing terhadap kebutuhan air, sinar matahari dan unsur hara.

\section{h. Pengendalian Hama Dan Penyakit}

Pada umur 24 HST tanaman sudah mulai terserang hama. Hama yang menyerang tanaman adalah ulat daun (Spedoptera, sp). Pengendalian dilakukan secara mekanik dengan cara meneliti tanaman secara seksama. Tanaman mulai terserang hama semut pada umur 60 HST yaitu menjelang panen, pengendalian yang dilakukan secara mekanik menggunakan kapur ajaib dengan cara melingkari polybag dengan bubuk kapur.

\section{1) Pemanenan}

Tanaman hotong di panen pada saat malai tanaman telah masak fisiologi yang ditandai dengan warna malai yang berwarna coklat.

Panen pertama dilakukan pada tanaman yang sudah masak fisiologi dan pemanenan dilakukan secara bertahap.

\section{2) Pengamatan}

Pengamatan dilakukan pada indikator pertumbuhan meliputi tinggi tanaman dan jumlah daun serta indikator produksi meliputi jumlah anakan (JA), jumlah malai (JM), panjang malai $(P M)$, bobot biji pertanaman (BBP), dan bobot kering brangkasan (BKB).

\section{HASIL DAN PEMBAHASAN}

Tabel 1. Uji Beda Rataan Jenis Pupuk Meliputi Tinggi Tanaman (TT) dan Jumlah Daun (JD) Pada Minggu Ke-8.

\begin{tabular}{ccc}
\hline \multirow{2}{*}{ Perlakuan } & \multicolumn{2}{c}{ Peubah Yang Diamati } \\
\cline { 2 - 3 } & TT & JD \\
\hline F1 & $132.66 \mathrm{~b}$ & $32.93 \mathrm{ab}$ \\
F2 & $130.66 \mathrm{~b}$ & $37.33 \mathrm{a}$ \\
F3 & $134.40 \mathrm{a}$ & $39.33 \mathrm{a}$ \\
F4 & $134.40 \mathrm{a}$ & $37.73 \mathrm{a}$ \\
BNJ 5 \% & 3.97 & 6.12 \\
\hline
\end{tabular}

Ket: Nilai rataan yang diikuti dengan huruf yang sama tidak berbeda nyata pada BNJ 0.05 .

Berdasarkan hasil uji beda perlakuan jenis pupuk minggu ke-8 (tabel 4.1) memperlihatkan bahwa pertumbuhan vegetatif tanaman hotong yang meliputi tinggi tanaman (TT), dan jumlah daun (JD). Dari hasil uji beda di dapati bahwa perlakuan F3 dan F4 memperlihatkan tinggi tanaman yang lebih tinggi, dan jumlah daun yang lebih banyak, bila dibandingkan dengan perlakuan lainnya.

Salah satu faktor lingkungan yang mempengaruhi pertumbuhan tanaman adalah tanah yang memiliki peranan sebagai media tumbuh, penyediaan unsur hara, penyediaan air untuk pernapasan akar tanaman (Tangmomere, 2013).

Tabel 2. Uji Beda Rataan Pupuk Meliputi Jumlah Malai (JM), Jumlah Anakan (JA), Panjang Malai (PM), Bobot Biji Pertanaman (BBP) dan Bobot Kering Brangksan (BKB).

\begin{tabular}{cccccc}
\hline \multirow{2}{*}{ Perlakuan } & \multicolumn{5}{c}{ Peubah Yang Diamati } \\
\cline { 2 - 6 } & JM & JA & PM & BBP & BKB \\
\hline F1 & $5.00 \mathrm{~b}$ & $5.00 \mathrm{~b}$ & $17.60 \mathrm{ab}$ & $19.77 \mathrm{~b}$ & $17.84 \mathrm{~b}$ \\
F2 & $5.06 \mathrm{~b}$ & $5.06 \mathrm{~b}$ & $17.53 \mathrm{ab}$ & $20.23 \mathrm{ab}$ & $18.62 \mathrm{ab}$ \\
F3 & $7.33 \mathrm{a}$ & $7.33 \mathrm{a}$ & $17.60 \mathrm{ab}$ & $37.98 \mathrm{a}$ & $18.82 \mathrm{ab}$ \\
F4 & $7.46 \mathrm{a}$ & $7.46 \mathrm{a}$ & $17.93 \mathrm{a}$ & $38.74 \mathrm{a}$ & $23.32 \mathrm{a}$ \\
BNJ 5\% & 3.05 & 3.05 & 0.40 & 23.7 & 5.55 \\
\hline
\end{tabular}

Ket: Nilai rataan yang diikuti dengan huruf yang sama tidak berbeda nyata pada BNJ 0.05. 
Pada peubah produksi (tabel 2) memperlihatkan perlakuan F4 (pupuk kotoran sapi) dan F3 (pupuk kotoran ayam) memacu komponen produksi terbanyak meliputi jumlah malai (JM), jumlah anakan (JA), panjang malai (PM), bobot biji pertanaman (BBP), dan bobot kering brangkasan (BKB). Hasil tersebut menunjukkan bahwa penggunaan pupuk kotoran sapi dan kotoran ayam mampu meningkatkan produksi tanaman. Pencapaian hasil terbaik pada parameter pengamatan tersebut karena penggunaan pupuk kotoran sapi memiliki kelebihan diantaranya kandungan haranya cukup baik, karena dapat menambah tersedianya bahan makanan atau unsur hara bagi tanaman yang dapat diserap dalam tanah untuk pembentukan malai tanaman hotong (Mayadewi, 2007).

Pupuk kotoran sapi juga mengandung kandungan fosfor yang sangat di perlukan tanaman untuk berproduksi maksimal. Menurut Sarif (1985) dalam Syam'un dan Ambo (2010) menambahkan bahwa fosfor berfungsi dalam pembelahan sel, dan juga untuk perkembangan jaringan meristem. Dengan demikian, fosfor dapat mempercepat pembungaan dan pemasakan buah. Selanjutnya ditambahkan oleh Novizan (2005) bahwa beberapa fungsi dari fosfor adalah pembentukan asam nukleat, menyimpan serta memindahkan energi ATP dan ADP, merangsang pembelahan sel, membantu proses asimilasi dan respirasi serta merangsang pembentukan bunga, buah dan biji. Selain itu dalam penelitian ini ternyata dengan penggunaan pupuk kotoran ayam juga menampakkan hasil terbaik pada peubah jumlah malai, jumlah anakan, panjang malai, bobot biji pertanaman, dan bobot kering brangkasan, hal ini disebabkan karena kandungan hara yang terdapat dalam pupuk kandang ayam cukup tinggi.

Menurut Syam'un dan Ambo (2010) menyatakan bahwa bahan organik melengkapi unsur-unsur esensial lainnya seperti hara mikro di samping bahan organik itu sendiri, sehingga dapat meningkatkan aktivitas jasad mikro yang akan memperbaiki sifat fisik, kimia dan biologi tanah. Menurut Fiolet et al., (1981) dalam Syam'un dan Ambo (2010) mengemukakan bahwa pupuk organik memperbaiki sifat kimia tanah, terutama meningkatkan bahan organik tanah dan kapasitas tukar kation tanah sehingga lingkungan pertumbuhan tanaman semakin membaik dan ketersediaan hara dapat meningkat.

\section{Tabel 3. Uji Beda Rataan Dosis Pupuk Meliputi Tinggi Tanaman (TT), dan Jumlah Daun (JD) Pada Minggu Ke-8.}

\begin{tabular}{ccc}
\hline \multirow{2}{*}{ Perlakuan } & \multicolumn{2}{c}{ Peubah Yang Diamati } \\
& TT & JD \\
\hline M0 & $125.41 \mathrm{~b}$ & $23.41 \mathrm{c}$ \\
M1 & $134.25 \mathrm{ab}$ & $41.50 \mathrm{ab}$ \\
M2 & $138.75 \mathrm{a}$ & $42.66 \mathrm{a}$ \\
M3 & $134.00 \mathrm{ab}$ & $42.08 \mathrm{a}$ \\
M4 & $132.75 \mathrm{ab}$ & $34.50 \mathrm{~b}$ \\
BNJ 5 \% & 3.97 & 6.12 \\
\hline
\end{tabular}

Ket: Nilai rataan yang diikuti dengan huruf yang sama tidak berbeda nyata pada BNJ 0.05.

\begin{abstract}
Berdasarkan hasil uji beda perlakuan dosis pupuk pada minggu ke-8 memperlihatkan pertumbuhan vegetatif yang meliputi peubah tinggi tanaman (TT) dan jumlah daun (JD). Dari hasil penelitian diperoleh bahwa (Tabel 4.3) perlakuan M2 (600 g/polybag) menunjukkan pertumbuhan tinggi tanaman tertinggi dan jumlah daun terbanyak, namun tidak berbeda dengan perlakuan M1, M3 dan M4. Hal ini menunjukkan bahwa dengan pemberian dosis pupuk $600 \mathrm{~g} /$ polybag sudah mampu menyumbangkan unsur hara pada tanaman hotong.
\end{abstract}


Tabel 4. Uji Beda Rataan Dosis Pupuk Meliputi Jumlah Malai (JM), Jumlah Anakan (JA), Panjang Malai (PM), Bobot Biji Pertanaman (BBP) dan Bobot Kering Brangkasan (BKB).

\begin{tabular}{cccccc}
\hline \multirow{2}{*}{ Perlakuan } & \multicolumn{5}{c}{ Peubah Yang Diamati } \\
\cline { 2 - 6 } & JM & JA & PM & BBP & BKB \\
\hline M0 & $3.91 \mathrm{c}$ & $3.91 \mathrm{c}$ & $10.83 \mathrm{~b}$ & $12.89 \mathrm{c}$ & $9.29 \mathrm{~b}$ \\
M1 & $7.33 \mathrm{a}$ & $7.33 \mathrm{a}$ & $18.83 \mathrm{ab}$ & $32.55 \mathrm{ab}$ & $20.90 \mathrm{ab}$ \\
M2 & $5.33 \mathrm{~b}$ & $5.33 \mathrm{~b}$ & $18.83 \mathrm{ab}$ & $23.56 \mathrm{~b}$ & $24.10 \mathrm{a}$ \\
M3 & $7.33 \mathrm{a}$ & $7.33 \mathrm{a}$ & $20.41 \mathrm{a}$ & $34.14 \mathrm{ab}$ & $22.97 \mathrm{ab}$ \\
M4 & $7.16 \mathrm{ab}$ & $7.16 \mathrm{ab}$ & $19.41 \mathrm{ab}$ & $42.76 \mathrm{a}$ & $21.00 \mathrm{ab}$ \\
BNJ 5\% & 3.05 & 3.05 & 0.40 & 23.7 & 5.55
\end{tabular}

Ket: Nilai rataan yang diikuti dengan huruf yang sama tidak berbeda nyata pada BNJ 0.05 .

Tabel 4 memperlihatkan komponen produksi pada perlakuan dosis pupuk menunjukkan nilai yang beragam, dari hasil analisis terlihat bahwa perlakuan M1 (300 g/polybag) dan M3 memperlihatkan nilai tertinggi pada peubah jumlah malai (JM) dan jumlah anakan (JA), terkecuali pada peubah panjang malai (PM) yang memperlihatkan perlakuan M3 (900 g/polybag) dan bobot biji pertanaman yang menunjukan perlakauan M4 (1200 g/polybag) serta peubah bobot kering brangkasan (BKB) yang memperlihatkan perlakuan M2 (600 $\mathrm{g} /$ polybag) terbaik bila dibandingkan dengan perlakuan M0 (kontrol) yang menunjukkan nilai terendah. Hal ini menunjukkan bahwa pemberian dosis pupuk M4 (1200 g/polybag), M3 (900 g/polybag) dan M2 (600 g/polybag) dan M1 (300 g/polybag) juga sudah mencukupi unsur hara yang dibutuhkan tanaman untuk menghasilkan produksi optimum pada tanaman hotong. Menurut Wididana (1993) dalam Djunaedy (2009) yang menambahkan bahwa dalam pemberian pupuk organik yang tepat dapat menggantikan atau mengurangi pemakaian pupuk kimia serta memberikan hasil atau produksi yang optimum. Sejalan dengan hasil analisis ragam pada peubah pertumbuhan menunjukkan pembentukan organ-organ vegetatif awal yang berlangsung dengan baik seperti pembentukan daun akan mendukung proses fisiologi tanaman yang sangat berperan dalam pembentukan malai tanaman hotong. Semakin banyak daun maka daerah asimilatnya semakin luas pula. Dimana proses fotosintesis terjadi di daun, dari hasil fotosistesis ini kemudian dimanfaatkan oleh tanaman untuk proses selanjutnya, yaitu pembentukan malai. Hal ini sejalan dengan pendapat yang dikemukankan oleh Djunaedy (2009) bahwa produksi tanaman biasanya dipengaruhi oleh pertumbuhan vegetatifnya baik dalam hal ini jumlah daun, maka ada kemungkinan produksinya akan baik pula. Hal ini sesuai dengan pendapat Salisbury, et al., (1995) yang menyatakan bahwa kapasitas fotosintesis meningkat dengan bertambahnya jumlah daun. 
Tabel 5. Uji Beda Rataan Interaksi Antara Jenis dan Dosis Pupuk Meliputi Tinggi Tanaman (TT), dan Jumlah Daun (JD) Pada Minggu Ke-8.

\begin{tabular}{cccc}
\hline \multicolumn{2}{c}{ Perlakuan } & \multicolumn{2}{c}{ Peubah Pertumbuhan } \\
\hline Jenis Pupuk & Dosis Pupuk & TT & JD \\
\hline \multirow{4}{*}{ F1 } & M0 & $131.33 \mathrm{~b}$ & $19.66 \mathrm{c}$ \\
& M1 & $137.66 \mathrm{a}$ & $36.00 \mathrm{ab}$ \\
& M2 & $135.33 \mathrm{a}$ & $38.66 \mathrm{a}$ \\
& M3 & $130.66 \mathrm{ab}$ & $36.00 \mathrm{ab}$ \\
$\mathrm{F} 2$ & M4 & $128.33 \mathrm{C}$ & $34.33 \mathrm{~b}$ \\
& M0 & $122.00 \mathrm{~b}$ & $30.00 \mathrm{~b}$ \\
& M1 & $131.33 \mathrm{ab}$ & $39.00 \mathrm{ab}$ \\
& M2 & $141.66 \mathrm{a}$ & $41.33 \mathrm{a}$ \\
F3 & M3 & $128.33 \mathrm{~b}$ & $41.00 \mathrm{a}$ \\
& M4 & $130.00 \mathrm{ab}$ & $35.33 \mathrm{ab}$ \\
& M0 & $125.33 \mathrm{~b}$ & $24.00 \mathrm{c}$ \\
& M1 & $129.66 \mathrm{~b}$ & $44.33 \mathrm{a}$ \\
& M2 & $129.66 \mathrm{~b}$ & $37.33 \mathrm{~b}$ \\
F4 & M3 & $144.00 \mathrm{a}$ & $41.00 \mathrm{ab}$ \\
& M4 & $143.33 \mathrm{a}$ & $35.33 \mathrm{~b}$ \\
& M0 & $123.00 \mathrm{~b}$ & $20.00 \mathrm{c}$ \\
& M1 & $138.33 \mathrm{ab}$ & $46.66 \mathrm{ab}$ \\
& M2 & $148.33 \mathrm{a}$ & $53.33 \mathrm{a}$ \\
& M3 & $133.00 \mathrm{ab}$ & $40.00 \mathrm{ab}$ \\
& M4 & $129.33 \mathrm{~b}$ & $28.66 \mathrm{~b}$ \\
& & 6.78 & 5.69
\end{tabular}

Ket: Nilai rataan yang diikuti dengan Huruf yang sama tidak berbeda nyata pada BN $\mathrm{J} 0.05$.

Tabel 6. Hasil Analisis Ragam Interaksi Antara Jenis Pupuk dan Dosis Pupuk Pada Peubah Produksi.

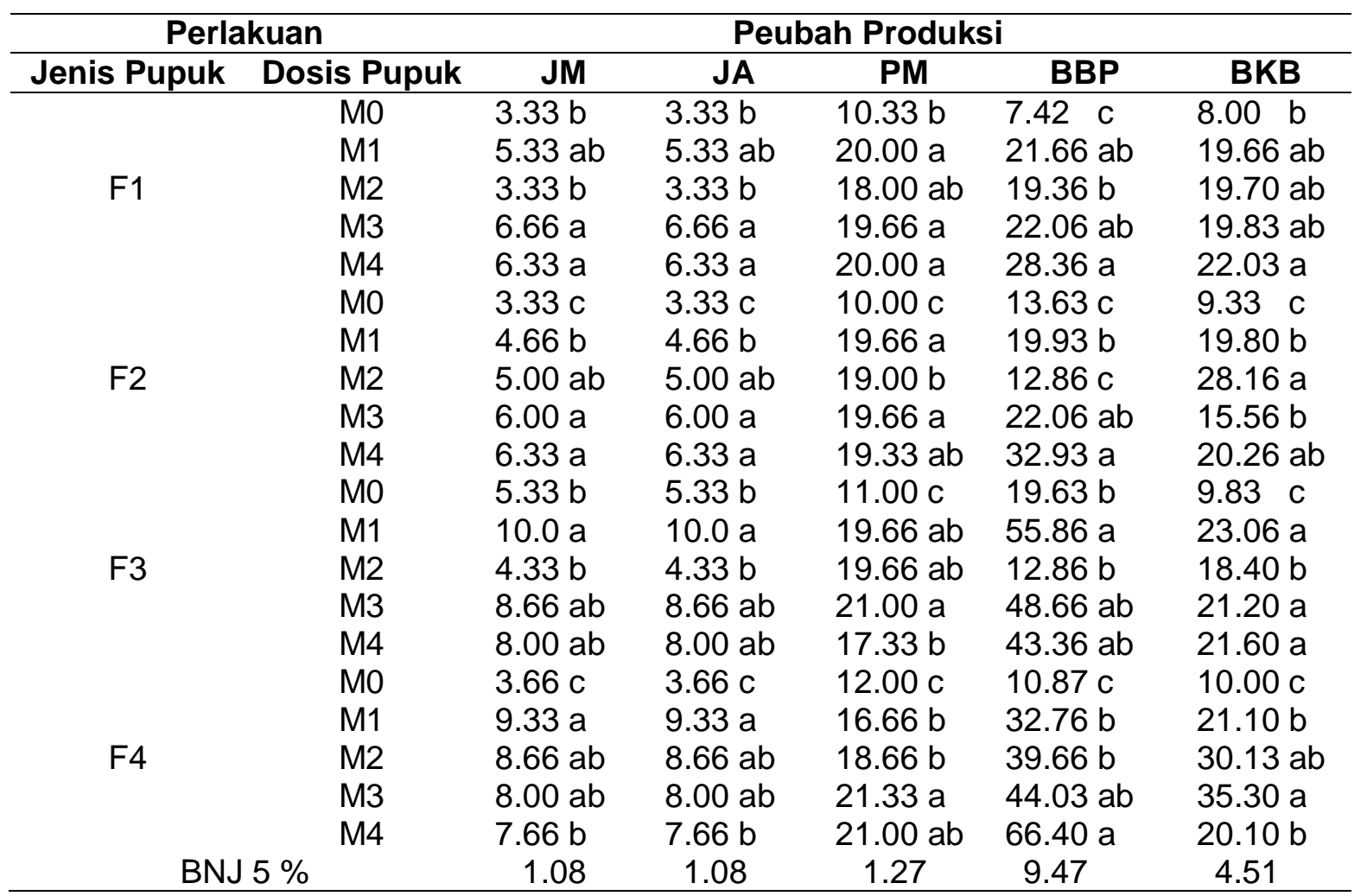

Ket: Nilai rataan yang diikuti dengan huruf yang sama tidak berbeda nyata pada BNJ 0.05 . 
Berdasarkan hasil uji beda interaksi perlakuan jenis pupuk dan dosis pupuk pada peubah pertumbuhan dan produksi tanaman hotong (tabel 5). Interaksi antara perlakuan jenis pupuk dan dosis pupuk pada pertumbuhan vegetatif minggu ke-8 meliputi peubah tinggi tanaman (TT) dan jumlah daun (JD) menunjukan adanya pengaruh jenis dan dosis pupuk pada pertumbuhan tinggi tanaman hotong, dilihat dari tinggi tanaman dan jumlah daun yang beragam.

Dari hasil penelitian memperlihatkan kombinasi perlakuan F4M2 (pupuk kandang sapi/600 g/polybag) menunjukan pertumbuhan tinggi tanaman tertinggi dan jumlah daun terbanyak bila dibandingkan dengan perlakuan lainnya. Hal ini menunjukan bahwa penggunaan jenis pupuk kandang sapi dengan dosis $600 \mathrm{~g} /$ polybag sudah memenuhi kebutuhan tanaman hotong, ini sesuai dengan pendapat yang dikemukakan oleh Gardner et al., (1991) dalam Sumiarjo (2011) menambahkan dan menyatakan bahwa nutrisi tanaman dan ketersediaan air mempengaruhi pertumbuhan atau perluasan sel seperti organ vegetatif atau organ pembuahan tanaman.

Hal ini juga disebabkan karena pupuk kandang sapi memiliki kandungan hara khususnya $\mathrm{N}$ yang dapat mempengaruhi perkembangan daun yang akan meningkatkan fotosintesis (AAK, 1981) dalam Tangmomere (2013). Penyediaan unsur hara terutama $\mathrm{N}$ dapat mempengaruhi perkembangan daun, sehingga akan meningkatkan fotosintat yang berarti meningkatkan fotosintat. Fotosintat tersebut selanjutnya ditranslokasikan keseluruh bagian tanaman yang mengakibatkan peningkatan pada bobot tanaman itu sendiri (Goldsworthy dan Fisher, 1996).

Hasil uji beda interaksi perlakuan jenis pupuk dan dosis pupuk pada peubah produksi yang meliputi peubah jumlah malai (JM), jumlah anakan (JA), panjang malai (PM), bobot biji pertanaman (BBP) dan bobot brangkasan kering (BKB) menunjukan adanya pengaruh jenis dan dosis pupuk pada tiap peubah produksi tanaman hotong, terlihat dari produksi tanaman hotong yang beragam pada tiap perlakuan. Dari hasil penelitian menunjukan bahwa kombinasi perlakuan F3M1 meningkatkan produksi malai dan anakan tanaman hotong, sedangkan pada kombinasi perlakuan F4M3 memperlihatkan hasil terbaik pada peubah panjang malai dan bobot kering brangkasan. Sedangkan kombinasi perlakuan F4M4 menununjukan hasil terbaik pada peubah bobot biji pertanaman, serta kombinasi perlakuan F4M3 memperlihatkan hasil terbaik pada peubah bobot kering brangkasan.

Peningkatan banyaknya malai yang menghasilkan biji hotong dengan bobot yang tinggi berhubungan erat dengan besarnya fotosintat yang ditranslokasikan ke bagian malai maka akan semakin meningkat pula bobot biji dari tanaman hotong. Pemberian pupuk kotoran ayam sudah dapat meningkatkan jumlah malai dan jumlah anakan serta pemberian pupuk kotoran sapi mampu meningkatkan panjang malai, bobot biji, dan bobot brangkasan tanaman hotong. Menurut Salisbury \& Ross (1992) dalam Maruapey (2011) menyatakan bahwa luas daun tanaman merupakan suatu faktor yang menentukan jumlah energi matahari yang dapat diserap oleh daun dan akan menentukan besarnya fotosintat yang dihasilkan. Fotosintesis tersebut sangat menentukan hasil biji karena sebagian fotosintat ditimbun dalam biji. Selama periode pengisian biji terjadi peningkatan akumulasi bahan kering dan kekurangan hara pada periode ini akan menyebabkan biji tidak berkembang penuh. Tersedianya hara yang cukup sepanjang pertumbuhan tanaman, dalam hal ini dengan pemberian pupuk kotoran ayam dengan dosis 900 g/polybag (F3M3) dan pupuk kotoran sapi dengan dosis 1200 g/polybag (F4M4) memberikan kemungkinan tanaman menimbun bahan kering yang lebih banyak. Hal ini terlihat dari hasil penelitian yang menunjukan bahwa kombinasi perlakuan F3M3 menunjukan bobot biji pertanaman yang tidak berbeda dengan perlakuan F3M1. Sedangkan kombinasi perlakuan yang terbaik diperlihatkan pada perlakuan F4M4 sebesar $66.40 \mathrm{~g}$ pada peubah bobot biji pertanaman. Dalam penelitian ini ternyata dengan memberikan pupuk kandang ayam dan sapi dengan dosis 900 dan 1200 g/polybag pertumbuhan dan perkembangan tanaman hotong menampakkan hasil terbaik yang akhirnya menghasilkan bobot biji hotong yang layak jual terbaik, hal ini 
disebabkan kandungan hara yang terdapat dalam pupuk kandang ayam dan sapi cukup tinggi. Dari hasil penelitian ini sejalan dengan hasil penelitian yang telah dilakukan oleh Zamriyeti (2005) dan Nyoman (2010) yang menunjukan penggunaan pupuk kandang ayam (30 ton/ha setara dengan 900 g/polybag) dan pupuk kandang sapi (40 ton/ha setara dengan $1200 \mathrm{~g} /$ polybag) dapat meningkatkan produksi jagung dan kacang tanah.

\section{KESIMPULAN DAN SARAN}

\section{A. Kesimpulan}

Berdasarkan hasil penelitian dan pembahasan yang telah di kemukakan sebelumnya maka, disimpulkan bahwa:

1. Adanya pengaruh pemberian jenis pupuk organik terhadap pertumbuhan dan poduksi tanaman hotong terlihat pada perlakuan jenis pupuk minggu ke-8 yaitu pada F3 dan F4 menunjukan pertumbuhan tinggi tanaman tertinggi, jumlah daun terbanyak, jumlah malai terbanyak, jumlah anakan terbanyak, panjang malai terpanjang dan bobot biji pertanaman terbanyak serta bobot kering brangkasan.

2. Adanya pengaruh dosis pupuk organik terhadap pertumbuhan dan produksi tanaman hotong terlihat pada perlakuan minggu ke-8 yaitu pada perlakuan M2, M3 dan M4 menunjukan pertumbuhan tinggi tanaman tertinggi dan jumlah daun terbanyak serta perlakuan jumlah malai dan anakan terbanyak, panjang malai terpanjang serta bobot biji pertanaman dan bobot kering brangkasan.

3. Rekomendasi pupuk yang efektif dalam pembudidayaan tanaman hotong adalah dengan penggunaan jenis pupuk kandang ayam dan sapi dengan dosis pemberian 900 dan $1200 \mathrm{~g} /$ polybag.

4. Interaksi antara perlakuan jenis pupuk dan dosis pupuk pada peubah pertumbuhan meliputi tinggi tanaman (TT) dan jumlah daun (JD) serta untuk peubah produksi panjang malai (PM), bobot biji pertanaman (BBP) dan bobot kering brangkasan (BKB) menunjukan adanya pengaruh jenis dan dosis pupuk pada tiap peubah pertumbuhan dan produksi tanaman hotong, terlihat dari pertumbuhan dan produksi tanaman hotong yang beragam pada tiap perlakuan.

\section{B. Saran}

1. Tanaman hotong menunjukan respon pertumbuhan dan produksi yang lebih tinggi pada perlakuan pupuk, dan penggunaan pupuk sangat berpengaruh terhadap pertumbuhan dan produksi tanaman hotong. Diharapkan dapat menjadi bahan informasi baik bagi peneliti maupun sebagai usaha-usaha demi peningkatan produksi dalam pembudidayaan tanaman hotong, khususnya di daerah Buru sebagai sentral produksi tanaman hotong dan daerah Maluku pada umumnya.

2. Dilakukan penelitian lanjutan dengan menggunakan jenis pupuk organik yang sama dengan dosis yang ditingkakan dari 900 dan $1200 \mathrm{~g} /$ polybag. Selain itu penelitian lanjutan juga dapat dilakukan pada lokasi yang berbeda yang sebelumnya belum pernah ditanami tanaman hotong.

\section{DAFTAR PUSTAKA}

Boonsiri, K., Dawrung, S., Siri Piromi., Angchree Sea-ang., Wirung Tong Ying., Jeerasak kontha dan Apiwat Weejitjan. 2009. Effects of Organic Fertilizer on the GrowthAnd Yield of Pak Choi and Rice Cv. Phitsonulok 60-2. Asian Journal of Food and Agro-Industry Special Issue, S 160-S 163.

Goldworthy. P.R. dan N.M. Fisher. 1996. Fisiologi Tanaman Budidaya Tropik Gajah Mada. University Press.

Hildayanti, 2012. Studi Pembuatan Flakes Juwawut (Setaria italica). Universitas Hasanudin. Makassar.

Lingga, P. Dan Marsono.2000. Petunjuk penggunaan Pupuk. Penebar Swadaya. Jakarta

Maruapey, A. 2011. Pengaruh Jarak Tanam Dan Jenis Pupuk Kandang Terhadap Pertumbuhan Dan Gulma Dan Hasil Jagung Manis. Seminar serealia. Hal 123-129

Mayadewi, A. 2007. Pengaruh Jenis Pupuk Dan jarak Tanam Terhadap Pertumbuhan Gilma Hasil Jagung Manis. Jurnal Agri, vol 26 (4): 153-159 ISSN: 02158620. 
Novizan. 2005. Petunjuk pemupukan yang efektif. Agro Media Pustaka, Jakarta.

Nyoman, S. 2010. Pengaruh Dosis Pupuk Terhadap Pertumbuhan dan Hasil Beberapa Varietas Kacang Tanah (Arachis hypogea L.). Universitas Udayana. Jakarta

Rumbawer F, 2003. Pokem Terigu Unggul Indonesia Masa Depan. Papuan Joernal Social and cultural Antropology.Laboratorium Antropologi Fakultas Ilmu sosial Politik. Universitas Cendrawasih. Jayapura.

Sarief E.S, 1995. Kesuburan dan Pemupukan Tanah Pertanian. Pustaka Buana. Bandung.

Sumiarjo, K. 2011. Penggunaan Abu Sekam Dan Pupuk ZA Terhadap Pertumbuhan
Dan Hasil Tanaman Tomat (Lycopersicum esculentum Mill). Embryo Vol. 8 No.1: 9-17.

Tangmomere., A. 2013. Respon pertumbuhan Dan Hasil tanaman Pokem (Pennisetum., SP) Pada Berbagai tingkat jenis dan Dosis Pupuk Organik.

Tim Pengembangan Hotong Buru. 2006. Pengembangan Hotong Buru Untuk Menunjang Ketahanan Pangan Nasional. Fakultas Teknologi Pertanian. IPB. Bogor.

Zamriyetti. 2005.Pengaruh Pupuk Kandang AyamTerhadap Pertuman Produksi Beberapa Varietas Jagung Semi (Baby corn). Jurnal Penelitian Bidang IImu Pertanian. 